"Social capital and social entrepreneurship and innovation culture"

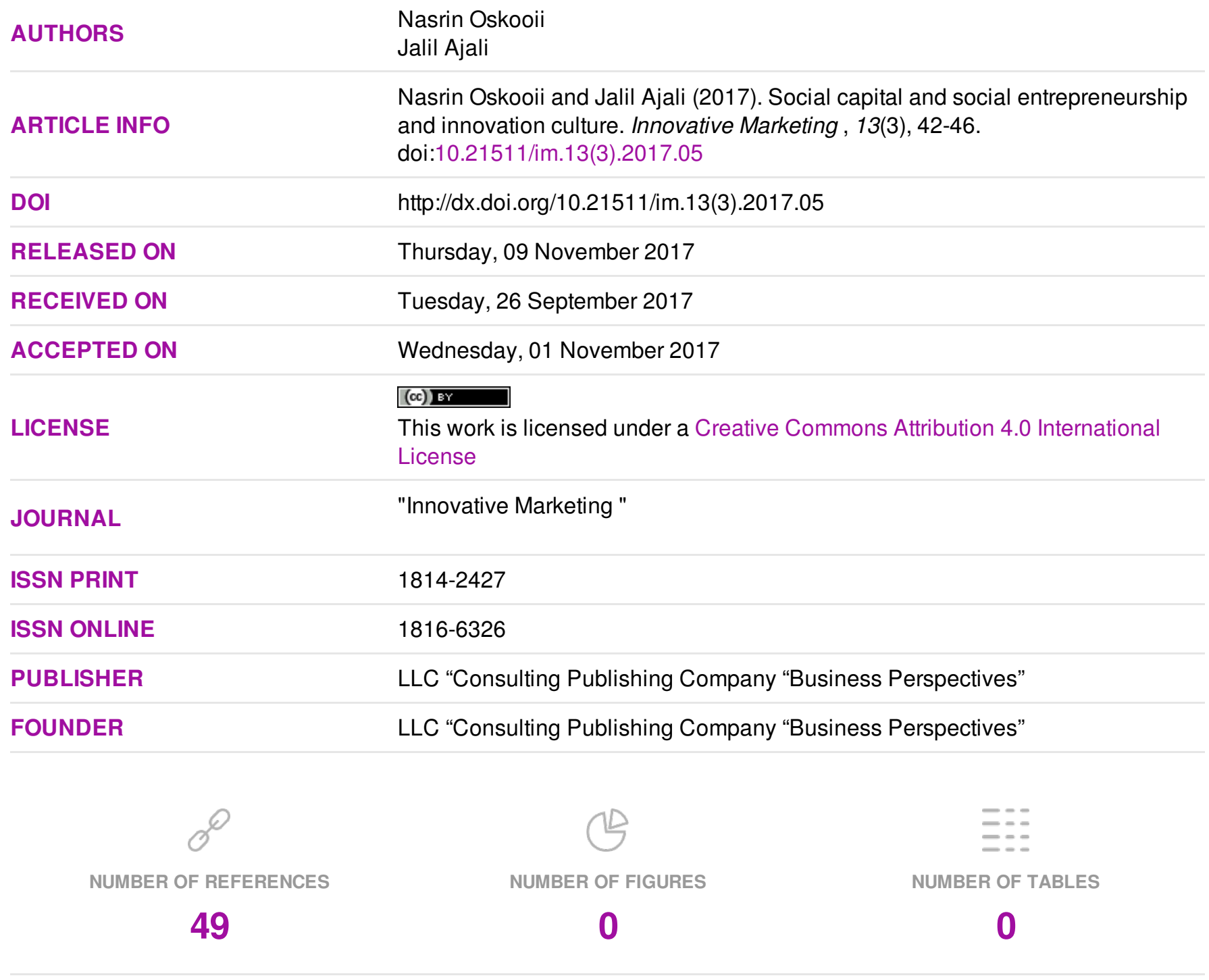

(C) The author(s) 2022. This publication is an open access article. 
Nasrin Oskooii (Iran), Jalil Ajali (Iran)

\title{
Social capital and social entrepreneurship and innovation culture
}

\begin{abstract}
Entrepreneurship is the mark and symbol of effort and success in business and entrepreneurs are the pioneers of successful businesses in the society. Their ability to take the opportunities, their strength in innovation and their capacity in succeeding are the standards which modern entrepreneurship is measured by. Entrepreneurs in leading, management, innovation, competency, job production, competition, efficiency and establishing new companies have an important role in economic growth. According to a kind of belief, entrepreneurship as a revolution is necessary for the societies. The importance of this revolution in current century is increasingly more than industrial revolution.
\end{abstract}

Keywords: social capital, social entrepreneurship, social capital quality and structural aspect, innovation, innovation culture.

JEL Classification: M19.

Received on: $26^{\text {th }}$ of September, 2017.

Accepted on: $1^{\text {st }}$ of November, 2017.

\section{Introduction}

Entrepreneurship is the mark and symbol of effort and success in business and entrepreneurs are the pioneers of successful businesses in the society. Their ability to take the opportunities, their strength in innovation and their capacity in succeeding are the standards which modern entrepreneurship is measured by (Brochaus \& Horwitz, 1986). Social capital increasingly is based on social and cultural factors and its recognition as a kind of capital in the macro management level or institutions and services management can give a new kind of understanding about socio-economical systems and help the managers in better leading of systems. Since entrepreneurship is a socio-economical process which is based on the status and context of society in two ways this kind of capital has an important role in the activities of entrepreneurs and, as a result, the existence or lack of social connections and communications effects the nature of business (Bolino, 2002).

\section{Social capital}

Up to now there have been different and variable definitions for the social capital. Pier Bourdieu believes social capital is the total physical or nonphysical, material or spiritual sources which allow a person or a group take a more or less established network of relations for mutual familiarity or cognition (Bourdieu, 1992). Robert Putnam, from the other side in his assessments, suggests that social capital is a collection of concepts such as confidence, norms and networks which cause an optimum connection and

(C) Limited Liability Company "Consulting Publishing Company "Business Perspectives", 2017.

Nasrin Oskooii, Department of Management, Faculty of Humanities, Islamic Azad University, Miyaneh, Iran.

Jalil Ajali, Department of Ecology, Faculty of Agriculture and Natural Resources, Islamic Azad University, Miyaneh, Iran. contribution between the members of a society and at the end provides their mutual benefits (Putnam, 2002).

\section{Structural aspects of social capital}

This aspect in terms of management structures and processes like responsiveness of managers and leaders according to their functions, transparency in decision making considers the degree of making decision and taking action according to group work and general pattern of dominant relationship in the society. This means that this aspect takes in toaccount the degree of relations between the people in the society (Bollino, 2002).

\section{The quality aspect of social capital}

This aspect is in terms of phenomena such as values, attitudes, commitments, partnership, and trust and includes the nature of social relations. In other words, since the structural aspect focuses on this question that weather the people have any relation, the quality aspect focuses on the quality of this relation (Bollino, 2002).

\section{The importance of social capital}

In the recent two decades, the concept of social capital in its different grounds and forms, as one of the most focal concepts, has been appeared and expressed. Even though it has developed a great deal of enthusiasm and passion among the researches and authorities, it has caused different attitudes, views, and expectations. The notable increase of research in this field expresses the importance and unique status of social capital in different social context. Generally speaking, the amount of social capital in each group or society represents the amount of trust that people have to each other (Pheyzy \& Faghihi, 1385). The existence of acceptable amount of social capital facilitates the social actions, so that in critical situations, social capital can be used as the main source for solving the problems and reforming current procedures. 
Hence, identifying the effective factors in boosting or weakening the social capital is of utmost importance (Ranani, 1385). Some of the main elements which can be used to measure social capital are:

- Understanding public political, social affairs and the presence of motivation among people who are seeking to obtain this sort of knowledge.

- Public mutual trust.

- Informal cooperative sharing in voluntary activities.

In general, we can say that one of the main factors for social capital recognition for target society is the form and the way of people relations and the state of coexistence among the people (Adler, 2002). Value of social capital for the personnel, specially for the knowledge personnel is drawn from this fact that social capital is the original source of power for the person and it is non transitional, that is personal social capital can not be directly transformed to some other people (Timmons, 2003). It depends on the person himself that be able to develop a kind of personal relation which would have mutual interest. An organization can not betake social capital to its personnel and in fact developing and expanding network of relations needs interpersonal skills and personal interests. Both the social capital and human capital have a high anthropic, that is for the creation and keeping and enhancing their value, both of them need a significant investment. In the case of social capital, if the energy is not frequently injected into the relations, it is possible that relations or even the persons themselves be forgotten (Entropy).

\section{Destructive effect of social capital}

Social capital has some costs and it can be destructive in some situations. A lot of studies have been performed on the advantages of using social capital, but less attention has been paid to the risks and threats of social capital. The first objection is related to the actorswho have the original and central role in social capital. Developing and keeping the social capital in an organization needs a large amount of financial investment to keep in place and maintain the relationships between the members. In some situations the advantages derived from social capital are so lower than the capital which is allocated to it (Alvany \& Taghavy, 1387).

\section{Relation of social capital with entrepreneurship}

Viclen believes that in addition to the economic elements such as market and capital advantages which affect the entrepreneur, noneconomic factors such as social relation networks can also affect the phenomenon of entrepreneurship. Social capital as a social phenomenon can lead to creativity, ideology, and it can facilitate the innovative behaviors and risk taking that could be one of the entrepreneurship indexes (Coleman, 1998). Those with higher amount of social capital have more access to the sources and information that can affect the development and formation process of business and access to the new market. Hence, social capital is of utmost importance to the entrepreneurs and those in social groups who have more social capital more likely are placed in profitable situations inside the networks, so it is more likely that they can discern business opportunities more effectively and can use them. To be involved in entrepreneurial activities, people should be able to monitor environmental changes and evaluate the effects of these changes over their newborn business. Failing of entrepreneur on forecasting his achievement in the business produces environmental hesitancy which in turn would stop his participation in entrepreneurial activities. Even though, social networks provide the skill and knowledge which reduces the existence of natural ambiguity in the process of entrepreneurship.

\section{The importance of social interactions in entrepreneurial activities}

Empirical studies show that social interactions play a major role in facilitating innovations and creativity which are among the indexes of entrepreneurship. Theorists have examined the relationship between social networks, the development of new ideas, and creativity. Also empirical and hypothetical studies have been carried out about the relation between social interaction and risk taking which are among other aspects of entrepreneurship (Nahapiet \& Ghoshal, 1996). Social relations through identification and exploration of threats and environmental opportunities and with implementing measures for neutralizing environmental hesitancy can lead to pioneering. Social relations also results in facilitating the knowledge transfer and implementation of social interaction not only benefits participants in these relations, but also people themselves with reducing the expenses and time in responding to the needs and environmental threats achieve some advantages. Recent researches suggest a connection between the network size and innovation, self renewal and entrepreneurship. The role of networks in boosting innovation and development of new ideas has been the subject of studies in recent years and their findings supports this hypothesis (Burt, 2000).

\section{Social entrepreneurship}

Certo and Miller (2008) define social entrepreneurship (SE) as a process that involves the recognition, evaluation and exploitation of 
opportunities that result in social value which involves the provision of basic needs such as food delivery, health services and education. SE is an activity with com-munity goals, which hopefully is profitable and the profitis used to reinvest in the organization itself (Steinerowski, Jack, \& Farmer, 2008). It is more likely to occur in con-texts where there are socio-economic, environmental and cultural issues (Dacin et al., 2010) and promotes a lasting, attractive and sustainable solution for social problems (Nga \& Shamuganathan, 2010). Social entrepreneurs are people who identify a failure in society and transform it into a business opportunity; they recruit and motivate others to their cause and build networks with essential people at the same time. Also, they face the obstacles and challenges and introduce their own systems to manage their social business (Thompson, 2002). Research on entrepreneurship highlights its importance in economic growth and development (Kirchhoff et al., 2013; Headd \& Kirchoff, 2009; Shane, 2006; Shane \& Venkataraman, 2000; Kirzner, 1979; Baumol, 1990; Schumpeter, 1934). New firms, particularly new high technology ventures with disruptive technologies, are important for job creation and contribute to distributing wealth (Kirchhoff et al., 2013; Spencer et al., 2008; Michelacci, 2003; Walsh et al., 2002; Birch, 1979).

Other research has focused on the behaviors of entrepreneurs and factors accounting for successful entrepreneurship (Gupta et al., 2004; Williams, 1983; de KetsVries, 1977; Honig, 1998) in contexts ranging from science and technology to micro enterprises in developing countries (Aldridge \& Audretsch, 2011). Governments in developing economies have made efforts to encourage entrepreneurship and technological innovation, given their importance, especially in small and medium scale business (Dolfsma \& Seo, 2013; Kang \& Park, 2012; Leff, 1979).

Entrepreneurship in developing countries, particularly at the base of the pyramid (Prahalad \& Hammond, 2002; Prahalad, 2007; London \& Hart, 2004) differs from that in the industrialized world (Silvestre \& Silva Neto, 2013; Walsh, 2012). In developing economies entrepreneurs must mobilize capital and specialized labor in imperfect markets characterized by poor information and rapid structural change (Walsh, 2012; Leff, 1979).

Likewise, diffusing technologies involves creating channels for input supply and sales and introducing disruptive innovations to serve new markets (Walsh, 2012; Christensen et al., 2003). Without entrepreneurship, investment in these activities might not occur. Social entrepreneurship is valuable in commercialization environments prevalent in developing economies as it refers to an ability to leverage resources and specifically address social problems (Dacin et al., 2010; Goldstein et al., 2008; Zahra et al., 2009). Often entrepreneurial efforts are stymied by a lack of available capital in developing countries due to insufficient demand (as in the case of renewable energy), thus increasing the risk and cost of innovation (Walsh, 2012). Consequently, other entities such as non-governmental organizations (NGOs) and academic institutions may assume a social entrepreneurship role to facilitate successful innovation.

\section{Social entrepreneurship and its development}

Social entrepreneurship is a young research area. Researchers in the field of social entrepreneurship showed diversified focuses and a unified definition was not found (Pless, 2012, p. 317; Short et al. 2009, p. 161; Dacin et al., 2011; Dacin et al., 2010). Dacin et al. (2011, p. 1211) pinpointed the importance of social processes in the pursuit of social entrepreneurship. They also indicated that social entrepreneurship theory should be constructed based on the following disciplines: institutions and social movements, networks, culture, identity and image cognition. A successful social entrepreneurship would contribute positively to the society. A valuable social entrepreneurship could provide constructive thoughts and motives that move the society onto the right track and arrive at a harmony state. Social entrepreneurship should broad social, cultural, and environmental goals, reach a high social satisfaction, and enhance social innovation. Social entrepreneurs would seek to transform societies at large. In order to reach a maximum outcome, social entrepreneurship must utilize information technology such as the Internet for facilitating communication capability.

\section{Innovation}

Innovation has become the core pillar of achievement for every organization in the current business world. Fast-evolving technology, shorter product life cycles and a higher rate of product development possibly boost the speed of innovation, which triggers changes in the nature of economic development. Innovation is now a core part of organizational strategies to achieve and sustain a competitive advantage in the market. It will be more complex due to rapid changes in customer wants and technology (Calantone et al., 2002).

\section{Innovation culture}

Corporate culture has been a fashionable topic since the early 1980s (Hofstede, 1991). During the last two decades, corporate culture has been acknowledged as an important component of 
organizational success (Irani, Beskese, Love, 2004). Johnson and Scholes defined it as a deeper level of basic values, assumptions and beliefs that are shared by the members of an organization (Johnson, Scholes, 1984). More specifically, innovation culture refers to the shared common values, beliefs and assumptions of organizational members that could facilitate the product innovation process. When an organizational culture or climate encourages the employees' innovation capacity, tolerates risk, and supports personal growth and development (Menzel, Aaltio, Ulijn, 2007), the organizational culture may be labelled as an 'innovation culture'.

\section{Conclusion}

The study shows that entrepreneurship drives economic growth and our country also can be one of the leading counties in entrepreneurial activity. Information, knowledge and practical-oriented entrepreneurial skills can be imparted for better results. Our country must build up a wide network of institutions which impart entrepreneurship education and training for prospective and existing entrepreneurs. The effectiveness of this network is considered as satisfactory. The study suggests a framework for entrepreneurship education and training which can be used to promote economic growth. Entrepreneurship as a strategic approach is an important element in the development of nations and societies. Nowadays because of enormous and basic changes in important areas of life such as economics and business, entrepreneurship is considered as a necessity. As entrepreneurship causes change and it is the result of creativity and innovation it is called as the most competitive excellence of institutes, nations and countries. The experts of entrepreneurship call it as a new lifestyle which is the origin of changes in all aspects of life. All of the values of entrepreneurship are the result of the entrepreneurs' interest toward creativity and innovation.

\section{References}

1. Adler, P. S. (2002). Social capital prospect for a new concept. Academy of management review, 12(1), 17-18.

2. Aldridge, T. T., Audretsch, D. (2011). The Bayh-Dole Act and scientist entrepreneurship. Research Policy, 40, 1058-1067.

3. Alvani, Seyed Mehdi, \& Taghavi, Mirali. (1985). Social capital, concepts and theories. Management Magazine, $34,11-12$

4. Baumol, W. J. (1990). Entrepreneurship, productive, unproductive and destructive. Journal of Political Economy, 98(5), 893-921.

5. Baumol, W. J. (1990). Entrepreneurship, productive, unproductive and destructive. Journal of Political Economy, 98(5), 893-921.

6. Birch, D. L. (1979). The Job Generation Process. Unpublished report prepared by the Massachusetts Institute of Technology Program on Neighborhood and Regional Change for the Economic Development Administration. Washington. DC: U.S. Department of Commerce.

7. Birch, D. L. (1979). The Job Generation Process. Unpublished report prepared by the Massachusetts Institute of Technology Program on Neighborhood and Regional Change for the Economic Development Administration. Washington, DC: U.S. Department of Commerce.

8. Bolino, Mark. (2002). Citizenship behavior and creation of social capital in organizations. Academy of management review, 27, 12.

9. Bourdieu, P. (1992). Forms of capital. In Handbook of theory and research the sociology of education (pp. 32-33). New York: Greenwood Press.

10. Brochaus, R., \& Horwitz, P. (1986). The psychology of the entrepreneurship. The art and the science of entrepreneurship (p.83). Ballinger: Cambridge, Mass.

11. Calantone, R. J., Cavusgil, S. T., \& Zhao, Y. (2002). Learning orientation, firm innovation capability, and firm performance. Industrial Marketing Management, 31(6), 515-524.

12. Certo, S., \& Miller, T. (2008). Social entrepreneurship: Key issuesand concepts. Business Horizons, 51, 267-271.

13. Christensen, C. M., Aaron, S., Clark, W. (2003). Disruption in education. Economics of Education Review, 38(1), 44-54.

14. Coleman, J. S. (1998). Absorptive capacity. Anew perspective on learning and innovation. Administrative science quarterly, 128-129.

15. Dacin, P., Dacin, M., \& Matear, M. (2010). Social entrepreneurship: Why we don't need a new theory and how we move forward fromhere. Academy of Management Perspectives, 38-57.

16. Dolfsma,W., Seo, DongBack. (2013). Government policy and technological innovation - a suggested typology. Technovation, 33, 173-179.

17. Faghihi, Aboulhasan, \& Feyzi, Tahere. (1985). Social capital and a new approach. Manangment Science, 72, 23.

18. FeyzBakhsh, AliReza, \& Baghiyari, HmidReza. (1983). Intrepreneurship, concepts and theories (p. 117). Sharif University: Science Publication.

19. Goldstein, J. A., Hazy, J. K., Silberstang, J. (2008). Complexity and social entrepreneurship: a fortuitous meeting. Emergence: Complexity and Organization, 10(3), 9-24.

20. Gupta, V., MacMillan, I., Surie, G. (2004). Entrepreneurial leadership: developing and measuring a cross-cultural 
construct. Journal of Business Venturing, 19, 241-260.

21. Headd, B., Kirchoff, B. A. (2009). The growth, decline and survival of small businesses: an exploratory study of life cycles. Journal of Small Business Management, 47(4), 531-550.

22. Hofstede, G. (1991). Cultures and organization: software of the mind. New York: McGraw-Hill.

23. Honig, B. (1998). What determines success? Examining the human, financial, and social capital of Jamaican entrepreneurs. Journal of Business Venturing, 13, 371-394.

24. Irani, Z., Beskese, A., Love, P. (2004). Total quality management and corporate culture: constructs of organizational excellence. Technovation, 24(8), 643-650.

25. Johnson, G., Scholes, K. (1984). Exploring corporate strategy. Englewood Clifss: Prentice-Hall.

26. Kang, Kyung-Nam, Park, H. (2012). Influence of government R\&D support and interfirm collaborations on innovation in Korean biotechnology SMEs. Technovation, 32, 68-78.

27. Kirchhoff, B. A., Linton, J. D., Walsh, S. T. (2013). Neo-Marshellian equilibrium versus Schumpterian creative destruction: its impact on business research and economic policy. Journal of Small Business Management, 51(2), 159-166.

28. Kirzner, I. (1979). Perception, Opportunity and Profit. Chicago and London: University of Chicago Press.

29. Leff, Nathaniel H. (1979). Entrepreneurship and economic development: the problem revisited. Journal of Ecoomic Literature, 17(1), 45-64.

30. London, T., Hart, S. L. (2004). Reinventing Strategies for Emerging Markets: Beyond the Transnational Model. Journal of International Business Studies, 35(5), 350-370.

31. Menzel, H., Aaltio, I., Ulijn, J. (2007). On the way to creativity: engineers as intrapreneurs in organizations. Technovation, 27(12), 732-743.

32. Michelacci, C. (2003). Low returns in R\&D due to the lack of entrepreneurial skills. The Economic Journal, 113(484), 207-225.

33. Michelacci, C. (2003). Low returns in R\&D due to the lack of entrepreneurial skills. The Economic Journal, 113(484), 207-225.

34. Nahapiet. J., \& Ghoshal, S. (2005). Social capital, intellectual capital and the organizational advantage. Academy of management review, 23.

35. Nga, J., \& Shamuganathan, G. (2010). The influence of personalitytraits and demographic factors on social entrepreneurship startup intentions. Journal of Business Ethics, 95, 259-282.

36. Prahalad, C. (2007). The Fortune at the Bottom of the Pyramid: Eradicating Poverty Through Profits. Pearson Educational/Wharton School Publishing, Upper Saddle River, N.J.

37. Putnam, R. D. (2000). Democracies in flux. The evolution of social capital in contemporarysociety. London: Oxford University Press.

38. Renani, Mohsen. (1985). The role of social capital in economic development. The social and cultural periodical magazine of Dariche, 4.

39. Schumpeter, J. A. (1934). The Theory of Economic Development, an Inquiry Into Profits, Capital, Credit, Interest, and the Business Cycle. Translated from the German by Redvers Opie. Harvard University Press, Mass, Cambridge.

40. Shane, S., Venkataraman, S. (2000). The Promise of Entrepreneurship as a Field of Research. Academy of Management Review, 25, 217-226.

41. Silvestre, B. S., Silva Neto, R. (2013). Capability accumulation, innovation and technology diffusion: lessons from a base of the Pyramid Cluster. Technovation http://dx.doi.org/10.1016/j.technovation.2013.09.007

42. Spencer, A. S., Kirchhoff, B. A., White, C. (2008). Entrepreneurship, innovation and wealth distribution: The essence of Creative destruction. International Small Business Journal, 26(1), 9-26.

43. Steinerowski, A., Jack, S., \& Farmer, J. (2008). Who are the socialentrepreneurs and what do they actually do? Babson CollegeEntrepreneurship Research Conference (BCERC). Frontiers of Entrepreneurship Research, 28(21).

44. Thompson, J. (2002). The world of the social entrepreneur. Inter-national Journal of Public Sector Management, $15(5), 412-431$.

45. Timmons. J. (2003). New venture creation (p. 175). Boston Homewood publisher.

46. Walsh, P. R. (2012). Innovation Nirvana or Innovation Wasteland? Identifying commercialization strategies for small and medium renewable energy enterprises. Technovation, 32, 32-42.

47. Walsh, S. T., Kirchhoff, B. A., Newbert, S. (2002). Differentiating market strategies for disruptive technologies. IEEE Transactions on Engineering Management, 49(4), 341-351.

48. Williams, E. E. (1983). Entrepreneurship, innovation and economic growth. Technovation, 2, 3-15.

49. Zahra, S. E., Gedajlovic, E., Neubaum, D. O., Shulman, J. M. (2009). A typology of social entrepreneurs: motives, search processes and ethical challenges. Journal of Business Venturing, 24(5), 519-532. 